Minier, Márta. "Translating Welsh Drama Into Hungarian Through English: A Contextual Introduction to Sêra Moore Williams' Crash in Hungarian Translation." Hungarian Cultural Studies. e-Journal of the American Hungarian Educators Association, Volume 6 (2013): http://ahea.pitt.edu DOI: 10.5195/ahea.2013.120

\title{
Translating Welsh Drama Into Hungarian Through English: A Contextual Introduction to Sêra Moore Williams' Crash in Hungarian Translation
}

\section{Márta Minier}

\begin{abstract}
This article offers a predominantly contextual introduction to my translation of a contemporary Welsh play by Sêra Moore Williams, Crash (2004), into Hungarian. Williams' three-person drama for young people was written originally in the author's native language, Welsh, and translated into English by the playwright herself. In my translation process of the play from English to Hungarian the intermediary role played by English raises ethical concerns from a postcolonial perspective, while in a pragmatic sense it is almost a necessity to rely on it when communicating Welsh-language cultural production to the broader international public, including to other minor languages. The article will place the drama in its generic context, introducing the play as a Theater in Education piece, as Williams' work has been inspirational in the development of tantermi színház [classroom theater] in Hungary since the early 2000s. As a specific case study within the case study, the additional discussion of the translation of Williams' polysemic title will provide an insight into the role such a significant paratext plays in uprooting a dramatic text from one culture to another.
\end{abstract}

Keywords: drama translation, Theater in Education, Sêra Moore Williams, Crash, minoritarian culture, translation between minor languages, Welsh drama in Hungarian, Welsh literature in Hungarian

Biography: Márta Minier is a Lecturer in Drama at the University of South Wales, UK. She holds a Ph.D. from the Centre for Performance Translation and Dramaturgy at the University of Hull, UK, where her Ph.D. thesis discussed the translation of Hamlet into Hungarian culture. Her main research interests include European drama with a special emphasis on Central and Eastern Europe; translation studies; adaptation studies; dramaturgy; stage and screen biography; children's culture; Hungarian studies; and Shakespeare studies with an emphasis on Shakespeare reception. She is Assistant Editor of the Journal of Adaptation in Film and Performance and one of the associate editors of the theater studies journal Symbolon.

This article is a predominantly contextual introduction to my translation of a contemporary Welsh play by Sêra Moore Williams, Crash, into Hungarian. After introducing the playwright, her work and Theater in Education - the genre in which Williams often writes-I will focus on the relatively new appearance of this theater genre in Hungary and Williams' contribution to its Hungarian emergence. I will then place the translation project in the broader context of translation from one minor language to another, highlighting theoretical influences on 
Minier, Márta. "Translating Welsh Drama Into Hungarian Through English: A Contextual Introduction to Sêra Moore Williams' Crash in Hungarian Translation." Hungarian Cultural Studies. e-Journal of the American Hungarian Educators Association, Volume 6 (2013): http://ahea.pitt.edu DOI: 10.5195/ahea.2013.120

my work, such as the concept of minoritarian art and polysystem theory. As a specific case study within the case study, the additional discussion of the translation of Williams' polysemic title will provide an insight into the role such a significant paratext plays in uprooting a dramatic text from one culture to another.

Sêra Moore Williams, a playwright, director and performer, worked extensively with the Wales-based site-specific theatre company, Brith Gof, between 1982 and 1994, while from the early nineties she was also writer/director of Y Gymaes, a company she established, "making work from a female perspective (Williams 2013)." From the mid-nineties for over a decade Williams worked for Arad Goch, a young people's theatre, as Associate Director enabling "young people who were on the edges of education for various reasons" (Williams 2013) to workshop their creative ideas and create performances. More recently, she has been a university lecturer of drama in the Welsh capital. Williams' plays for young people tackle pressing social issues, such as broken homes, alcohol- and drug-related problems and the general neglect of young people within society.

Crash (2004), Williams' three-person drama for young people commissioned and first produced by the Welsh language Arad Goch Theatre Company, was written originally in the author's native language, Welsh and translated into English by the playwright herself, alongside some of her other plays. The play has enjoyed notable success on stage in both languages and has been a set text for GCSE Drama in Wales both in Welsh and in English. It is to be replaced on the GCSE curriculum with Williams' most recent play, Mwnci ar Dan/Burning Monkey, which is the first bilingual English-Welsh drama publication by Bloomsbury and focuses on an intergenerational encounter between a teenage couple and an older war veteran.

As David Adams' review for Theatre in Wales (2007) emphasises, Crash is a play "of the clashes and crashes of adolescence." The drama features three teenagers, Elin (or Els), Wes and Rhys, who are "almost 16" and would like to be treated as grown-ups. Els, who comes from a supportive family that she finds more and more stifling, falls for Wes, who is from a troubled family background and is supervised by a social worker, presumably as part of the fostering network. Wes, while longing for affection and stability, introduces Els to what she sees as the forbidden pleasures of youth, such as underage drinking and driving "borrowed" cars, stolen for joyriding mostly with the intention of returning them. The third character, Rhys, like Els, also comes from a supportive background and, unlike Els's, his teenage rebelliousness is hardly noticeable. Although Rhys has been Elin's good friend from school for a long time, she is growing apart from him under the influence of Wes. She wishes to break away from home and quit school just before the exams. The tensions in and around the budding romance between Elin and Wes mount to a crisis, and the two young people - first Elin, then Wes - appear at the seashore at Craig yr Wylan. From there a desperate Elin phones her always reliable friend Rhys: "Everything's crashing down all 'round me" (69). Rhys hasn't learnt yet how to drive but sneaks out of his parents' house and sits in his mother's car. He is hesitant about borrowing it to go and get Elin. We leave him pondering, and while Elin and Wes calm down and seem to make their separate ways from the shore, the play leaves it open whether Rhys leaves for Els in the car that he is not ready to drive. As will be discussed later, this purposefully truncated ending brings into focus at least one of the meanings of the title Crash.

There are crashes of different kinds throughout the play, including computer crashes, crashes by the protagonists at someone else's home (informal usage) and, towards the end of the play, Wes crashes in a borrowed car, escaping with light injuries. Still, we are not told whether there is a final and possibly fatal crash at the end, which is for the audience to decide. Crash, as 
Minier, Márta. "Translating Welsh Drama Into Hungarian Through English: A Contextual Introduction to Sêra Moore Williams' Crash in Hungarian Translation." Hungarian Cultural Studies. e-Journal of the American Hungarian Educators Association, Volume 6 (2013): http://ahea.pitt.edu DOI: 10.5195/ahea.2013.120

well as a previous play by Williams, Son, is inspired by a real-life event of which the playwright read in a newspaper, where it was alleged that there may have been some sort of a suicide pact between a young boy and girl in the Welsh coastal town of Aberystwyth, where the girl jumped, fell or was pushed and ended up hurt while the boy didn't get hurt but emerged from the situation as a particularly troubled young man (Williams 2013). Another inspiration for this play for Williams was Driving Me Crazy, a performance the vulnerable young people she had worked with at Arad Goch had earlier created about "borrowing" cars.

Several of Williams' plays, which include (to cite them by their English titles) Confetti (2002), Son (2002), Riff (2005), Burning Monkey (2007) and Crash, emerge from the British tradition of Theater in Education (TIE). Rather than aiming at direct didacticism, this kind of theater intends to challenge the thinking of young people and prompt them to take a position in relation to the social content and ethical dilemmas presented. Priding themselves on freshness of thought as opposed to high production values, TIE performances travel from school to school and are usually followed by question and answer sessions between the student audience and the production team. A dialogic and consciousness-raising form, TIE is famous for its "creative gaps" or indeterminacies, to use the literary theorist Wolfgang Iser's terms as appropriated by Anthony Jackson (2007: 180).

The TIE approach to theater helps shape the personality, the individual's sense of identity, moral compass and worldview. As practitioner and scholar of Theater in Education, Roger Wooster $(2007: 23,26)$ argues, TIE "is not about training feelings but understanding feelings" and "[it] could be neither identified as 'pure theatre' nor 'pure education'." In a similar vein, Stuart Bennett's succinct definition of TIE (2005: 244) focuses on the pivotal role of the actor-teacher. This type of theatre, a somewhat Aristotelian bettering of the soul, is not designed to happen by spoon-feeding ideologies to the audience member but through the spectator's own agency in the interpretation and collective discussion of the theater experience, and at times, even including a more hands-on participation on behalf of the audience. As Helen Nicholson (2009: 19) puts it: "This theatrical pedagogy sought to encourage young people to participate in theatre as a learning medium and as a vehicle for social change." Although TIE is undoubtedly a contentious genre, which regularly divides theater-makers, pedagogues and critics, it certainly is a format which can be said to re-engage theater performance with the classic aesthetic principle of miscere utile dulci. Throughout my own translation of Crash I have reminded myself of Jackson's (2007: 160) summative view that this format can only be "effective educationally [...] if it is effective aesthetically."

Rooted in Brechtian political theater and having emerged alongside the community, agitprop and otherwise alternative theaters in the mid 1960s in England and in 1972 in Wales (Wooster 2007: 21; 6), the TIE format is well-rehearsed in Britain, where it is currently enjoying a revival due to the engagement of such a high profile and socially committed playwright as Edward Bond, among others. Yet, it is comparatively little-known in Hungary and other Hungarian-speaking communities in Hungary's neighbouring countries. Nevertheless, the form is getting better known in Hungary gradually, at least in part due to the inspiration taken from Sêra Moore Williams through the theater-maker János Novák, who singled her work out at an international festival in Seoul, where it was representing British youth theater. Within a Hungarian context Williams, in translation, can be seen as a contemporary pioneer of nonmainstream drama for young people. The first presentation of Williams' work in Hungary was the staging of her deeply metatheatrical 2001 play Mab (in her own English translation: Son), by the Budapest puppetry and children's theater Kolibri in the 2002-2003 season in Péter Horváth's 
Minier, Márta. "Translating Welsh Drama Into Hungarian Through English: A Contextual Introduction to Sêra Moore Williams' Crash in Hungarian Translation." Hungarian Cultural Studies. e-Journal of the American Hungarian Educators Association, Volume 6 (2013): http://ahea.pitt.edu DOI: 10.5195/ahea.2013.120

translation from the English version and under his direction. The production, entitled A mi fiunk [Our Son], and starring József Tóth, Bea Tisza and Dávid Szanitter, was regarded by Novák (2003) as "our first performance for teenagers" [elsö saját, kamaszoknak szóló elöadásunk]. The piece was also featured as part of Kolibri's twelfth international festival in 2003. Mab, originally commissioned by the Welsh National Eisteddfod for the 2001 festival is, like Crash, also a threehander - a play for three actors - for one female and two male performers. Although it may be read as a modern-day version of the oft-retold and almost archetypal Martin Guerre story, it is based on a real-life event: the disappearance of a thirteen-year-old boy and his alleged reappearance after three years. As in the case of Martin Guerre, the youth who returns is not the "prodigal son" but another drifting young man looking for a home.

Since Kolibri's 2001 production of Williams' Son, there has been a heyday of drama for young people in Hungary, resulting in a spate of touring productions specifically scripted and directed for teenagers. Some of these have been mostly shortened adaptations of required readings from the Hungarian secondary school curriculum, such as Antigone, Örkény's oneminute stories, or the 2007 hamlet.ws directed by Árpád Schilling for Krétakör, a theater performance that is identified as a benchmark for some later youth-oriented productions (on which see further Nánay). Other productions are issue-led plays specifically scripted so as to raise ethical questions with young people. For example, three plays, all translated into Hungarian by Kristóf Kovács, are: Klamm háborúja [Klamm's War], a monodrama by Kai Hensel produced by Kolibri in 2008 which looks at the teacher-student relationship and where a teacher's responsibilities and remit may end; Lutz Hübner's Kikatt, produced by Kolibri and directed by Péter Scherer in 2009 which tackles the sensitive subject of physical violence by students against teachers; Monoblock's three-hander Helló, náci, also directed by Scherer for Kolibri in 2010 which targets xenophobia and political extremism. Importantly, a few acclaimed Hungarian playwrights have tried their hands at the genre recently: István Tasnádi’s Cyber Cyrano and Ákos Németh's A webáruház [The Webstore] are both on Kolibri's 2013-2014 repertoir. Apart from the pioneering work of Kolibri, several smaller, not traditional theater-building based companies have also started producing tantermi szinház [classroom theatre]. Topical titles recently presented at the Tantermi Színházi Projekt showcase include Menj Európába! [Go to Europe], a play about young immigrants into Hungary, presented by Lakmusz Csoport [Lakmusz Group] and Szkéné's Kö, papirr, olló [Rock, Paper, Scissors], which is about migration from Hungary. A specific 2011-2012 initiative for producing new plays for teenagers was primarily funded by a private memorial fund, Polgár Krisztina Emlékalap and coordinated by Füge (Függetlenül Egymással Közhasznú Egyesület) [Independently with Each Other Public Benefit Association]. The fact that the two competitively selected rounds of productions were subsidised privately rather than by the state emphasises the genre's non-mainstream nature and relative novelty in Hungary.

Crash may be seen as an example of what various scholars such as Rosi Braidotti and Anton Pujol term minoritarian art (as opposed to majoritarian art), drawing on a term coined by Gilles Deleuze and Félix Guattari in their Kafka: Toward a Minor Literature (1986), in relation to Franz Kafka and other writers who were writing in a language other than the national language of the country they lived in. Minoritarian literature is political because of its minority status, and it may be engaged in "setting up a minor practice of a major language from within" (Deleuze and Guattari 1986: 18) as English language writing does in Wales, or write against the grain in the minor language itself. Moreover, Crash is minoritarian or, in Braidotti's famous phrase, becoming-minoritarian (always in the process of redefining itself) from more than one 
Minier, Márta. "Translating Welsh Drama Into Hungarian Through English: A Contextual Introduction to Sêra Moore Williams' Crash in Hungarian Translation." Hungarian Cultural Studies. e-Journal of the American Hungarian Educators Association, Volume 6 (2013): http://ahea.pitt.edu DOI: 10.5195/ahea.2013.120

perspective: it is a play originally written in Welsh but in a postcolonial, devolved Wales. The story itself originated in Wales (although it might easily have happened elsewhere); the play was written by a female playwright and in a non-mainstream style. It is unsurprising that such a production might not sit easily in a traditional, merely realist or naturalist, theater-building based setting. Also, Theater in Education is generally perceived to be on the margins of professional theater-making, and is more aligned with applied drama. As it tends to be publicly funded, its independent, anti-establishment status is more of a myth for some of its critics (see Howard Barker's criticism, analysed in Nicholson 2009), yet the relatively low visibility of the genre within contexts of a canonising force warrants its perception as marginal for the purposes of this study. Importantly, playwright Nina Rapi (1997: 236, 237), who is of Greek cultural identity but writes her plays in English, mentions TIE among what she calls minority theatre: "I believe that the so-called minority theatre: black, lesbian, perhaps TIE [Theatre in Education] can bring about change." She finds such forms as "potentially subversive". In an interview for the collection

Feminist Stages: Interviews With Women in Contemporary British Theatre, Welsh speaker Sharon Morgan, an actress, laments the very limited presence of female writers on the Welshlanguage theatre scene, and mentions Serra Moore Williams, among another few practitioners (see De Gaye 1997) - yet another reason for the play's minoritarian status. Importantly, as Williams points out, "the fact that [Crash is] open-ended may have as much to do with my being a female writer as it does with any other genre" (Williams 2013).

As far as my translation enterprise is concerned, with this project I am testing the potential and lifeblood of the genre as a scholar-translator, and in framing the overall translation project in scholarly terms, I have found polysystem theory instrumental. While relatively little has been written systematically in terms of cultural theory on cross-fertilisation between minor cultures, the set of perspectives and terminology of polysystem theory - a systemic and functional school of translation and cultural theory emerged in the seventies - can throw some light on the macrostructures from and into which a process of cultural translation takes place. As one of the key proponents of this approach, Itamar Even-Zohar (1978: 24) explains, translation can play a primary role when a literature (in his term, polysystem) is young, that is, in the process of foundation; when it is weak or peripheral; or when it goes through a crisis or is at a crossroads. Once the culture has become established and self-sufficient, for example in AngloAmerican contexts and France, translation can be treated as a secondary activity, and there is no longer any urgent need for much translation activity (see Gentzler 1993: 118). As Even-Zohar (2010: 54; 62-63) discusses, one frequent motive for translation is as a way to introduce new genres or text types into a national culture that is either a developing one or one that has not been familiar with that particular genre. As I elaborated above, in the case of Williams' Crash and Son, the translations contribute to the gradual establishment of a particular theater genre in Hungary and Transylvania, where the first rehearsed reading — and publication —of Crash is going to take place.

In Wales, new cultural products are created in Welsh, English or bilingual versions, but from the rich palette of contemporary Welsh writing relatively little travels to other languages and cultures, and when it does so it is almost inevitably through the intermediary of English. It is therefore not surprising that there is little communication between the Hungarian and the Welsh systems of dramatic literature. Although the shortage of translations of contemporary Hungarian creative writing is less striking than that of translations from Welsh, Hungarian literature, too, often only reaches foreign shelves because of an earlier translation into a widely read language of high prestige, such as German. 
Minier, Márta. "Translating Welsh Drama Into Hungarian Through English: A Contextual Introduction to Sêra Moore Williams' Crash in Hungarian Translation." Hungarian Cultural Studies. e-Journal of the American Hungarian Educators Association, Volume 6 (2013): http://ahea.pitt.edu DOI: 10.5195/ahea.2013.120

A relatively recent case in point is the international bestseller that emerged from Hungarian, Sándor Márai's rediscovered novel, A gyertyák csonkig égnek [Embers], which reached the global English-speaking community as Christina Viragh's German translation was retranslated into English by Carol Brown Janeway (2001) (see further, Sherwood 2011 and Komporaly and Minier 2008, see also the article in this issue by Bálint Szele on Shakespeare translations in Hungarian, sometimes through the intermediary of German). While over the course of Western translation history heavily adapted versions of texts based on intermediary rather than direct sources were often accepted as translations, today's publishers tend to prefer first-hand knowledge of the original language when commissioning translations. Even though in the case of minor languages like Hungarian it is not always possible to find available translators even into a widely spoken, and even less so to another minor language, the authenticity of such re-translations becomes particularly problematic, or as the English playwright Michael Frayn eloquently puts it, retranslating a translation is like "performing brain surgery wearing thick gloves" (quoted in Rappaport 2007: 75). In this quote, Frayn is referring to the use of so-called literals: very close translations prepared by native speakers for perusal by the playwright responsible for the final reworking of the text for a particular performance. This is a widespread practice in contemporary British theater; however, the English version of Crash is done by the playwright herself, which she has directed back-to-back with the Welsh version three times so far. Williams is perfectly accustomed to and content with regularly creating two versions of her plays, for the sake of reaching a broader audience. The situation appears more complicated if the intermediary language is one with which the respective culture is in somewhat of a postcolonial relationship with, as is the case with English in Wales. Even though the Welsh cultural critics today are divided over whether their current culture is in a postcolonial phase or a postnational stage of their history, there is a certain irony about the cultural travels of Welsh-language creative works through a relay language carrying historical connotations of dominance and oppression (on various perspectives on the contextualisation of contemporary Welsh culture see Aaron and Williams).

For a miniature case study within the case study, I now turn to the complexity of rendering the title of Crash into Hungarian. Title translations are a crucial part of the complex hermeneutic as well as creative process that we call translation. Importantly, titles designate or identify a text, and in a translation context the new title contributes to establishing a new identity for the translated work. The translated title therefore has the distinct ontological function of assisting the integration of an artifact into a receiving culture. In Christiane Nord's (1995: 261) work on titles and headings, where she draws on a corpus of German, French, English and Spanish examples, titles are perceived as "a text-type in their own right." Among various other functions of the title, Nord identifies the metatextual work titles perform. Indeed, titles operate as interpretive aids to the critic, translator and, in the case of the theater, to the entire production team from director to designer, to actor and the marketing department. As Andrei Bantaş (1994: 79) reminds us, the translator's work on a title is a significant part of the "manifold 'dissection' of the original (which no other reader but a translator - not even a literary critic - would undertake)." Gérard Genette's concept of the paratext—a subtype of transtextuality in Genette's taxonomy, which he also discussed in a separate volume: Paratexts: Thresholds of Interpretation - has led various translation scholars (Gerber, Józan, Minier) to comment on title translation in the light of semi-textual phenomena belonging to the pragmatic dimension of the text in question. Genette, drawing on the work of Charles Grivel and Leo Hoek, distinguishes between thematic and formal/rhematic titles: the former primarily comment on the subject matter 
Minier, Márta. "Translating Welsh Drama Into Hungarian Through English: A Contextual Introduction to Sêra Moore Williams' Crash in Hungarian Translation." Hungarian Cultural Studies. e-Journal of the American Hungarian Educators Association, Volume 6 (2013): http://ahea.pitt.edu DOI: 10.5195/ahea.2013.120

of the text, the latter on the style or genre. When setting out to select an appropriate title for Williams' play the above theoretical considerations have been very influential.

As David Adams' (2007) review of Crash emphasises, "[Crash is] a popular title, maybe because it sums up [...] modern life: with or without an exclamation mark, as in computer crash, as in gatecrash, as in crash out, as in crash editing, as in crash metal, as in car crash." So let's see how this suggestive and metaphoric title may translate, when to the best of my knowledge, there isn't a semi-equivalent in Hungarian that would be equally polysemic and would carry very similar connotations. While it is not difficult to identify a choice of Hungarian words for "car crash'-karambol or the more formal ütközés - these won't convey the slang meaning of staying somewhere unofficially which also features very predominantly in the dialogue. Neither will they communicate the meaning of everything crashing or collapsing in the female protagonist Elin's life or the meaning of one collapsing or crashing out of exhaustion or as an effect of certain substances. If karambol-'car crash'-were to be used in the Hungarian title and throughout the text, the play would not be able to remain open-ended, which would be a deviation from the author's own reading, a reading which I am lucky enough to be aware of, due to regular communication with Williams. While moving away from authorial intention or interpretation is, of course, inevitably bound to happen in translation in some way, what is more alarming perhaps is disturbing the integrity of the drama with determining what, in Iser and Jackson's term, we might perceive as an indeterminacy, that of the open ending. Csattanás, another standard Hungarian word for "crash", emphasises the noise and intensity of the crash, hence, contrary to karambol, it could be a very appropriate choice, but it has the disadvantage of not having the polysemy of the English and adopted Welsh word. I was at some stage in my translation process drawn to still another word, koccanás, which is much less intensive than crash - more like 'bump' or perhaps 'knock' — but I felt that it would not refer adequately to the problem all the three young people have with their respective families, in different measures, as bumps, unlike crashes, are not high risk enough.

When a foreign title offers particular problems of translation, as does that of Crash, another solution is the non-translation, that is, leaving the original title, but this is as an extreme foreignizing gesture, where the translator decides to retain or reconceive a heightened element of foreignness in the text and paratexts, and such a choice carries its own consequence (for a detailed discussion see Venuti 2008). Non-translation may be somewhat more frequent in the case of films and television programmes than on stage, although one may find-very fewtheatrical exceptions, for instance Zsófia Bán's translation of Mark Ravenhill's Shopping and Fucking, where the title stays unchanged in the Hungarian translation. Another strategy is to keep the foreign language title but precede it or follow it with a target language translation, for example as in Féktelenül - Speed, Madmen - Reklámörültek or, once again, Mark Ravenhill's Product - A termék translated and directed by Ádám Berzsenyi Bellaagh for Merlin. In the case of Crash, leaving the title merely in English seemed to me to be potentially alienating for the average audience member with no or little English to understand its many layers, and a joint Hungarian title such as Karambol would limit the interpretative choices for production team and audience alike. An early discussion with Sêra Moore Williams threw light on one of the German productions of the play. This performance, despite being an ambitious and well-received project, seemed to do away with the open ending, introducing the sound of police and ambulance sirens in the finale: "it seemed that the production had already made its mind up" (Williams 2013). In contrast, when Williams discusses the play with young people in schools and asks them about the resolution, the answers are "always half and half, not cut and dry" (Williams 2013). The 
Minier, Márta. "Translating Welsh Drama Into Hungarian Through English: A Contextual Introduction to Sêra Moore Williams' Crash in Hungarian Translation." Hungarian Cultural Studies. e-Journal of the American Hungarian Educators Association, Volume 6 (2013): http://ahea.pitt.edu DOI: 10.5195/ahea.2013.120

playwright, however, does not resent this further adaptation of the work in other languages and cultures. Even though she notes that the play, in that particular German performance "was used for something completely different", she maintains that "as long as it works for them, [...] it works" (Williams 2013). Even so, as a translator-scholar I felt that in order to facilitate rather than hamper the reception process a greater creative leap seemed necessary in the translation of the title.

The young people's dialogue features mermaids in line with the recurrent theme of the sea, and mermaids feature in an important, character-setting conversation between Els and Wes. Trying to build on this important leitmotif, I gave plenty of consideration to formulating this significant paratext from one of the two following lines, among other possibilities: "A hableányok is veszélyesek, ugye?" [Mermaids are dangerous too, aren 't they?] or "A hableányok nem süllyednek el?" [Don't mermaids sink?] The first sentence comes from Wes: "Mermaids are dangerous too aren't they?" (14). The second sentence is the appropriation of Wes's question to Els: "How come mermaids don't drown?" [Hogy lehet, hogy a hableányok nem süllyednek el?] (11).

When Elin and Wes discuss future career aspirations, Wes, at least half jokingly, wants to be an international drug dealer and Elin wants to be a mermaid. Wes reminds us that mermaids can be dangerous as they can "Make men crash their boats" (15). Elin does bring danger to some degree to Wes. She talks him into crashing with friends so that she doesn't have to be at home when Wes should clearly sleep elsewhere as he will be checked by the social worker. Els also asks Rhys to do something dangerous and potentially fatal when she asks him to fetch her in a car from the coast. Using one of these two quotations from the script for the title may put too much emphasis on Elin as a character, who is to be envisaged as of an equal role in an ensemble of three performers, but would highlight key themes of the play. It would emphasise the play's poetic nature and its connections with myths and legends. It might, perhaps unfortunately, also have a didactic streak, which the original title certainly hasn't got. Even though I would like to emphasise the dialogic rather than the didactic aspect of the play in my translation, I shouldn't disregard the reading of the play as a cautionary tale for teenagers. Without spoonfeeding young adults, Crash alerts teenagers to the responsibilities they take with their various decisions, and it may also highlight that they are not so alone with their quests for identity or teenage rebellions. Sêra Moore Williams (2013) wanted "to write a short play with big emotions" rather than an overtly educational piece. This, too, alongside my drive to experiment along the lines of translation as creative writing, encouraged me to search further along the lines of metaphors and leitmotifs for the title (for more on translation as/and creative writing see for instance Bassnett and Bush 2006; Loffredo and Perteghella 2006).

My "final" choice for the title, then, is Sellöfiu, sellölány [Merboy, Mermaid]. This mythical and metaphorical title has a poetic hue, partly because of the asyndeton. Selloffiu, sellölány is expected to engage and intrigue potential audience members and is in a strong transtextual connection with the play, as conversations about mermaids (and, as Elin adds, mermen) provide a frame to the action. In the first scene we meet a daydreaming Elin, who appears grateful to Wes for saving him from the sea after pushing her into it probably below the picturesque Craig yr Wylan. As Rhys is unable to drive, Wes is apparently unable to swimElin welcomes the miracle in the midst of what she sees as a grey and limited teenage existence. Elin fantasises about mermaids and, later in the play, angels. The prominence of angels and the appearance of devils in a later key scene underline a second generic stratum of the play, that of mediaeval morality plays. In the final scene, the leitmotif of the mermaid (and merman) features 
Minier, Márta. "Translating Welsh Drama Into Hungarian Through English: A Contextual Introduction to Sêra Moore Williams' Crash in Hungarian Translation." Hungarian Cultural Studies. e-Journal of the American Hungarian Educators Association, Volume 6 (2013): http://ahea.pitt.edu DOI: 10.5195/ahea.2013.120

even more prominently. While Elin dreams about what it would be like to drown like a mermaid, Wes tries to talk Elin into a joint suicide, in vain - more of a call for help and attention from him, as the two youths eventually leave to make their way back, separately. Even though my title does not carry the multiple meanings of the original title, at least it addresses a prevalent leitmotif of the text, which is key to the interpretation of a play about teenage loneliness, desires and search for identity. The absence of Rhys in the title's referential system is apparent and regretable; yet, a production that is based on a careful reading of the play will be unlikely to relegate him to the role of a hopeless sidekick, for he carries much importance in this ensemble piece. The title I have managed to construct is mainly thematic but it makes a comment on the play's style and generic ramifications as well.

To sum up, this article has offered a context to a contemporary play from Wales newly translated into Hungarian. As the cultural wealth of Wales - especially Welsh-language or bilingual work - has little visibility in the Hungarian cultural polysystem such a project raises awareness within the receiving culture and hopes to encourage further cultural encounters of a similar nature. By illustrating how a paratext such as a title contributes to uprooting a play-a blueprint for performance, in Worthen's words 1 - from one dramatic context to another my exploration has focused predominantly on genre and culture both in the original and the receiving context, though other aspects of the translation process - for example identifying the relevant sociolect - are also instructive, and deserve separate treatment elsewhere. Emphatically, a theater script can hardly be called definitive as it is subject to ongoing dramaturgical treatment, so I will bow my head if there are textual changes to be introduced when the script is put to the test. There are also various aspects of the play that the translation may or may not hint at but they are best tackled in performance. While I translated the details of the contribution of the musician/DJ closely, following Williams' stage directions, on the stage a lot will depend on how the director deals with the live music element, which is somewhat less frequent on Hungarian stages. Likewise, the way the text is embodied and enunciated by the actors will add further interpretive layers to the text. In line with the source text, I did not include any dialects prominently, but the director can easily introduce this purely by casting actors who speak (or are trained to speak) with a particular accent. Moreover, casting for example a Roma actor in the role of Wes may incorporate the text even more visibly and meaningfully into contemporary culture. While the class difference issue is certainly implied in the English-language text, in Hungary or Transylvania an ethnicity issue may be fruitfully added to the play's negotiation of the social divide.

${ }^{1}$ W. B. Worthen in Drama: Between Poetry and Performance discusses several metaphors - the score, the blueprint, information and software - that attempt to describe the complex relationship between plays on the page and theatre. All these expressions have valuable interpretive connotations as well as limitations. 
Minier, Márta. "Translating Welsh Drama Into Hungarian Through English: A Contextual Introduction to Sêra Moore Williams' Crash in Hungarian Translation.” Hungarian Cultural Studies. e-Journal of the American Hungarian Educators Association, Volume 6 (2013): http://ahea.pitt.edu DOI: 10.5195/ahea.2013.120

\section{Works Cited}

Aaron, Jane and Williams, Chris (eds). 2005. Postcolonial Wales. Cardiff: University of Wales Press.

Adams, David. 2007. "An involving and an intelligent piece of theatre: Crash". Theatre in Wales: Theatre, Dance and Performance Reviews. http://www.theatrewales.co.uk/reviews/reviews_details.asp?reviewID=1565.

Bantaş, Andrei. 1994. "Names, nicknames, and titles in translation." Perspectives: Studies in Translatology 2. 1 79-87.

Bassnett, Susan and Bush, Peter (eds.) 2006. Translation and Creative Writing. London and New York: Continuum.

Bennett, Stuart (ed.). 2005. Theatre for Children and Young People: 50 Years of Professional Theatre in the UK. Aurora Metro.

Branchadell, Albert and West, Lovell Margaret (eds). 2005. Less Translated Languages. John Benjamins.

De Gaye, Jane. 1997. "Sharon Morgan on Welsh Women's Theatres" in Goodman, Lizbeth and De Gaye, Jane (eds). Feminist Stages: Interviews With Women in Contemporary British Theatre, Routledge., 272-277.

Deleuze, Gilles and Guattari, Félix. 1986. Kafka: Toward a Minor Literature. Translated by Dana Polan. Minneapolis and London: University of Minnesota Press.

Even-Zohar, Itamar. 1978. Papers in Historical Poetics. Tel Aviv: Tel Aviv University.

Even-Zohar, Itamar. 2010. Papers in Culture Research. Tel Aviv: The Culture Research Laboratory [Electronic Book] http://www.even-zohar.com.

Genette, Gerard. 1997. Paratexts: Thresholds of Interpretation. Translated by Jane E. Lewin. Cambridge: Cambridge University Press.

Gentzler, Edwin. 1993. Contemporary Translation Theories. London: Routledge.

Gerber, Leah. 2008. "Paratextual Mediation in Translation: Translating the Titles of Australian Children's Fiction into German, 1945-the Present." Monash University Linguistic Papers 6. 1: 41-50.

Jackson, Anthony. 2007. Theatre, Education and the Making of Meanings: Art or Instrument? Manchester: Manchester University Press.

Józan, Ildikó. 1997. "Műfordítás és intertextualitás [Literary Translation and Intertextuality]." Alföld: 11.

Komporaly, Jozefina and Minier, Márta. 2008. "Adaptation, Translation, Multimediality: A Hungarian Bestseller Across Cultures." Journal of Adaptation in Film and Performance 1. 3: 191-204.

Loffredo, Eugenia and Perteghella, Manuela (eds). 2006. Translation and Creativity: Perspectives on Creative Writing and Translation Studies. London and New York: Continuum.

Minier, Márta. 2000. "Szentivánéji álmok (A magyar Shakespeare-kánon útvesztői) [A Midsummer Night's Dreams: The Labyrinths of the Hungarian Shakespeare Canon]." Átváltozások 19: 147-156.

Minier, Márta. 2003. "Egy fogadatlan prókátor megjegyzései a Jelenkor Hungarológiafórumához [Marginal Notes to Jelenkor's Hungarian Studies Forum]." Jelenkor 46. 5: 560-568. 
Minier, Márta. “Translating Welsh Drama Into Hungarian Through English: A Contextual Introduction to Sêra Moore Williams' Crash in Hungarian Translation." Hungarian Cultural Studies. e-Journal of the American Hungarian Educators Association, Volume 6 (2013): http://ahea.pitt.edu DOI: 10.5195/ahea.2013.120

Nánay, István. 2011. "Színház az osztályteremben. Tantermi Színházi Projekt / MU Színház [Theater in the Classroom: The Classroom Theater Project/MU Theater]." Revizor. A kritikai portál (4 March) http://www.revizoronline.com/hu/cikk/3166/tantermi-szinhazi-projekt-mu-szinhaz/

Nicholson, Helen. 2009. Theatre \& Education. Palgrave Macmillan.

Nord, Christiane. 1995. "Text-Functions in Translation: Titles and Headings as a Case in Point." Target 7. 2, 261-284.

Novák, János. 2003. "Gyerekszínház, körü-belül [Perspectives on Children’s Theatre]." Beszélö 8. 6

Pujol, Anton. 2010. "The Cinema of Ventura Pons: Theatricality as a Minoritarian Device". Journal of Adaptation in Film and Performance, 3. 2: 171-184. Rappaport, Helen. 2007. "Chekhov in the Theatre: The Role of the Translator in New Versions" in Anderman, Gunilla M. (ed.), Voices in Translation: Bridging Cultural Divides. Clevedon: Multilingual Matters. 66-77.

Sherwood, Peter. 2011. "On the German and English Versions of Márai's A gyertyák csonkig égnek (Die Glut and Embers)", Tötösy de Zepetnek, Steven and Vasvari, Louise O. eds. Comparative Hungarian Cultural Studies, Purdue University Press, 113-122.

Venuti, Lawrence. 2008. The Translator's Invisibility: A History of Translation. 2nd ed. London and New York: Routledge.

Williams, Sêra Moore. 2009. Crash. Aberystwyth: Atebol.

Williams, Sêra Moore. 2013. Interview with Author. (February)

Wooster, Roger. 2007. Contemporary Theatre in Education. Bristol and Chicago: Intellect. Worthen, W. B. 2010. Drama: Between Poetry and Performance. John Wiley and Sons. 